\title{
Use of Oil Drill Cuttings as an Alternative Raw Material in Sandcrete Blocks
}

\author{
Babagana Mohammed and Christopher R. Cheeseman* \\ Department of Civil and Environmental Engineering, \\ Imperial College London, South Kensington, London SW7 2AZ, UK
}

\begin{abstract}
This research has investigated the use of waste oil drill cuttings treated by thermal desorption in sandcrete, a major construction material used throughout Nigeria and much of West Africa. Sandcrete samples were prepared using a sand to cement ratio of $6: 1$. The results show that replacing up to $50 \mathrm{wt} . \%$ of sand by treated oil drill cuttings produced sandcrete with reduced water absorption and reduced sorptivity, increased density and reduced thermal conductivity. In addition, the compressive strengths of samples containing oil drill cuttings were comparable to control samples. The work demonstrates the potential for the beneficial reuse of waste oil drill cuttings treated by thermal desorption in the production of sandcrete blocks with improved properties.
\end{abstract}

Keywords: sandcrete; oil drill cuttings; waste reuse; sorptivity, water adsorption, Nigeria

\section{Introduction}

Sandcrete is manufactured from sand, Portland cement and water, without the addition of any coarse aggregate. It is a very important construction material throughout much of Nigeria and West Africa [1]. Recent studies have reported typical mechanical properties of sandcrete, which is normally used in the form of solid or hollow blocks. Sandcrete can have appropriate properties for use in construction if properly manufactured [2]. These include relatively high compressive strength, low shrinkage, low thermal conductivity and high density [3-7].

Oil drill cuttings (ODC) are the fine fragments of rock produced by drilling. They are typically composed of sandstone or shale in Nigeria, and have particles sizes ranging from $10 \mu \mathrm{m}$ to $1-2 \mathrm{~cm}[8]$. ODC are carried to the surface by drilling mud which is separated and re-injected. ODC are often discharged into the sea or dumped on land, and this can have significant adverse environmental impact [9].

\footnotetext{
* Corresponding author

Tel: +44 207594 5971; Fax: +44 207823 9401; Email address: c.cheeseman@imperial.ac.uk
} 
Oil and gas exploration and production generates very large quantities of ODC $[9,10]$. Nigeria has over 3,500 oil platforms and typically 100-1600 tonnes/well of ODC are produced during exploration and 9001400 tonnes/well during well development [11]. Various management options for ODC have been reported and these include onsite disposal of ODC via slurrification and annular injection, offshore reinjection, phytodegradation using mature reed wetland, use of processed ODC for wetland restoration, treatment by landfarming, microwave treatment, stabilisation/solidification and bioremediation of soil contaminated with ODC [12-25]. However, there are issues associated with each of these options, and none represents a total management solution for ODC.

ODC are increasingly being treated by low-temperature thermal desorption (LTTD) in Nigeria. A schematic of the LTTD process is shown in Figure 1. This removes residual hydrocarbons and water by evaporation followed by condensation. LTTD is capable of treating oil-based mud/cuttings and extracting/recovering the hydrocarbon content that evaporates below $325^{\circ} \mathrm{C}$. Heavy oils do not evaporate at this temperature and these organic fractions remain in the treated ODC. Recovered oil can be recycled into drilling fluids or used as fuel. The treated oil drill cuttings (TODC) have less than 1 wt.\% hydrocarbon content, which is below the existing Nigerian regulatory limits for off-shore or on-shore disposal. Waste TODC are normally disposed of to land but are a consistent material with potential to be beneficially reused.

Raw materials for construction products are subject to stringent and restrictive environmental regulations in Nigeria and there is a need to find alternative sources. Sand is the major component in sandcrete and obtaining suitable sand can be problematic. Using TODC as a replacement for sand in sandcrete would represent a large scale beneficial recycling option of a readily available waste material. The objective of this work was to investigate the potential for using TODC as a replacement for sand in sandcrete blocks.

\section{Experimental}

Materials

Oil drill cuttings treated by LTTD were obtained from Delta Environmental Logistics Limited, Nigeria. CEM I (Lafarge Cement), sand (Thames Valley River sand) and distilled water were used in the production of all samples. TODC were characterised for moisture content, oil content by loss on ignition (LOI) at $550^{\circ} \mathrm{C}$, dry loose density and $\mathrm{pH}$ with crystalline phases determined by $\mathrm{x}$-ray diffraction (XRD, 
Philips P1830 diffractometer with $\mathrm{Cu} \mathrm{K \alpha}$ radiation and a secondary graphite crystal as monochromator). As-received TODC were oven dried at $105^{\circ} \mathrm{C}$ for 24 hours before being used to prepare sandcrete blocks.

Both the sand and the dried TODC were passed through a $1 \mathrm{~mm}$ sieve before use.

Sandcrete block production

Sandcrete control samples were prepared using a sand to cement ratios of 6:1. Additional samples were prepared with TODC replacing the sand, as shown in Table 1, with all samples prepared using constant water to solids (w/s) ratio of 0.125. Blocks were mixed and cast in accordance with BS EN 196-1:2005 [27]. $50 \times 50 \times 50 \mathrm{~mm}$ blocks were produced using a vibrating table to remove air voids. Samples were demoulded after 24 hours, weighed and transferred to polyethylene re-sealable plastic bags containing a damp tissue to maintain a humid environment. They were cured for 28 days at room temperature $(25 \pm$ $2^{\circ} \mathrm{C}$ ) before testing. All the block samples were produced and tested in triplicate.

Test methods

Consistency

The consistency of each slurry mix was determined following BS EN 1015-3:1999 [28]. This used a 255 mm diameter flow table with a $100 \mathrm{~mm}$ diameter conical mould, and involves filling the mould with the test mix and levelling. The mould was then removed and mix subjected to 15 standard rapid vertical displacements. The resulting spread of the mix determines consistency.

Density

Sample density was determined in triplicate using Archimedes method as:

Density $=\frac{m_{d r y}}{\left(m_{\text {sat }}-m_{\text {imm }}\right)}\left(\mathrm{g} / \mathrm{cm}^{3}\right)$

where $m_{d r y}=$ the dry mass of block in air $(\mathrm{g})$

$$
\begin{aligned}
& m_{s a t}=\text { the saturated mass of block in air }(\mathrm{g}) \\
& m_{\text {imm }}=\text { the immersed mass of block in water }(\mathrm{g})
\end{aligned}
$$




\section{Water absorption}

Water absorption was determined in accordance with BS 1881-122: 1983 [29]. The test was conducted in triplicate and the average reported. The procedure involved immersing blocks in water for 24 hours, with the water surface kept $25 \pm 5 \mathrm{~mm}$ above the top of the block. The blocks were then dried with a damp absorbent cloth, and the sample weighed. The difference between the initial dry weight and the saturated weight gives the water absorption according to the formula:

$$
\left[\frac{\left(w_{s a t}-w_{d r y}\right)}{w_{d r y}}\right] \times 100 \%
$$

where $w_{\text {sat }}=$ the saturated weight of the block $(\mathrm{g})$

$$
w_{d r y}=\text { the initial dry weight of the block }(\mathrm{g})
$$

\section{Unconfined compressive strength}

Unconfined compressive strength (UCS) was determined using an Automax 5 Series compression testing machine under a loading rate of $300 \mathrm{~N} / \mathrm{s}$ in accordance with BS 12390-3:2002 [30] on samples dried at $40^{\circ} \mathrm{C}$ before testing. The test was conducted in triplicate and the average reported.

\section{Sorptivity tests}

Sorptivity measures the water absorption of a material due to capillary rise. The sorptivity of the samples was measured in accordance with BS EN 480-5:2005 [31] and as used in other studies [32-35]. The test set up shown in Figure 2 involved supporting block samples on a wire-mesh platform immersed in water. The depth of submersion of the blocks was kept constant at $3 \mathrm{~mm}$ throughout the 120 minute duration of the test. The cumulative volume of water absorbed by each block was measured by recording the individual weight gained by each block after one minute and at 5 minutes intervals thereafter, with weight gain graphed against the square root of time. The test was conducted in triplicate and the average data reported. The sorptivity $\mathrm{S}$ is then given by the slope of the line as [36]:

$$
i=S t^{\frac{1}{2}}
$$


where $i=$ cumulative volume of water absorbed per unit-cross sectional area and $\mathrm{t}$ is the elapsed time.

\section{Thermal conductivity}

Thermal conductivity was determined using a TT-TCP Thermo Physical Measurement Instrument (Thermo Test Inc.) which is an interfacial, non-destructive testing method. This is an important parameter in tropical climates where temperatures can be in excess of $45^{\circ} \mathrm{C}$ and walls need to control the internal building temperature. The heat flow from the sensor through the surface of blocks was used to determine the thermal conductivity. Samples were pre-dried at $40^{\circ} \mathrm{C}$ before testing with tests conducted in triplicate with the average reported.

Micro-structural analysis

The microstructures of selected blocks were analysed using scanning electron microscopy combined with energy dispersive x-ray spectrometry on gold coated polished surfaces (SEM-EDX, JEOL-JSM-840A).

\section{Results}

As-received TODC had a moisture content of $9.1 \mathrm{wt} . \%$, loss on ignition of $8.4 \mathrm{wt} . \%$ and dry loose bulk density of $1.32 \mathrm{~g} / \mathrm{cm}^{3}$. XRD data given in Figure 3 shows that the major phases present in the as-received TODC were quartz $\left(\mathrm{SiO}_{2}\right)$, barite $\left(\mathrm{BaSO}_{4}\right)$ and calcite $\left(\mathrm{CaCO}_{3}\right)$, with possible traces of hematite $\left(\mathrm{Fe}_{2} \mathrm{O}_{3}\right)$, ankerite $\left(\mathrm{Ca}(\mathrm{Fe}, \mathrm{Mg}, \mathrm{Mn})\left(\mathrm{CO}_{3}\right)_{2}\right)$, kaolinite $\left(\mathrm{Al}_{2} \mathrm{Si}_{2} \mathrm{O}_{5}(\mathrm{OH})_{4}\right)$ and illite $\left(\mathrm{Al}_{2}\left(\mathrm{Si}_{3.2} \mathrm{Al}_{0.8}\right) \mathrm{O}_{10}(\mathrm{OH})_{2} \mathrm{~K}_{0.8}\right)$.

Mix consistence

Figure 4 presents mix consistence data. The consistence of mixes was a maximum when $30 \mathrm{wt} . \%$ TODC was used, with values of $130 \mathrm{~mm}$ for the $6: 1 \mathrm{mix}$. Lower values were recorded at $10 \mathrm{wt} \%$ TODC. Mixes with TODC contents > $50 \mathrm{wt} . \%$ were very dry and the consistence could not be determined. Sandcrete mix consistency was not significantly affected by the addition of up to $30 \mathrm{wt} . \%$ TODC, but at higher additions increased water was required to achieve similar flow properties. 
Figure 5 shows average density data for triplicates. This indicates an increase in density with TODC addition, with a broad density maximum between 40 - 70 wt.\% TODC. Up to 70 wt.\% TODC contents are associated with increased density but reduced flow properties. The sand and TODC are well compacted and produce a dense sandcrete body. TODC has a much finer particle size than sand and blends well with Portland cement, resulting in dense compacted samples. Control of the combination of fine TODC and sand can produce a range of materials with different densities.

Water absorption

Figure 6 shows that water absorption decreased with increasing TODC for both mixes, presumably as a result of the increased residual oil content. The data points are the average of samples tested in triplicate. The results show that the water absorption of the blocks was significantly below the 12 wt.\% limit specified by NIS 87:2004 [37]. The reduction in water absorption with increased TODC addition can be attributed to the hydrophobic nature of TODC resulting from the residual-oil content and the dense packing between the sand and TODC particles. Above 70 wt. $\%$ TODC content the water absorption increased as sandcrete block density decreased. However, samples with $40-70$ wt.\% TODC content exhibited good packing and low water absorption.

Unconfined compressive strength

Average unconfined compressive strength (UCS) data for sandcrete blocks tested in triplicate containing different amounts of TODC is shown in Figure 7. The UCS peaked at $\sim 20$ wt. $\%$ TODC but then reduced slightly. Using up to $50 \mathrm{wt} \%$ TODC produced sandcrete with UCS significantly higher than the minimum specified in NIS 87:2004 [37]. The minimum UCS specified in Nigerian building regulations was achieved when using up to 70 wt.\% TODC content and these samples had more than twice the specified UCS. When the replacement was increased to $80 \mathrm{wt} . \%$ TODC the UCS value was significantly less than required.

Sorptivity

Figure 8 illustrates the sorptivity results for blocks containing TODC. Samples containing $~ 50$ wt. $\%$ TODC had very low sorptivity $\left(0.039 \mathrm{~g} / \mathrm{mm}^{1 / 2}\right)$. Samples with $90-100$ wt.\% TODC had increased 
sorptivity $\left(\sim 0.416 \mathrm{~g} / \mathrm{mm}^{1 / 2}\right)$ with results similar to those obtained for control samples ( $0 \mathrm{wt} . \%$ TODC content, $0.410 \mathrm{~g} / \mathrm{mm}^{1 / 2}$ ). The results are average data from tests completed in triplicate. The TODC addition correlated with the sorptivity of the blocks. The high density of 50 wt.\% TODC content sandcrete combined with the residual-oil in TODC produced very low sorptivity sandcrete.

Thermal conductivity

The effect of TODC content on thermal conductivity is shown in Figure 9 and results in a progressive decrease. The thermal conductivity of sandcrete blocks and four other construction materials is shown and reduced from 1.74 to $0.46 \mathrm{~W} / \mathrm{m} . \mathrm{K}$ with increased addition of TODC. Samples were tested in triplicate. The results for other materials were $1.7 \mathrm{~W} / \mathrm{m} . \mathrm{K}$ for concrete, $0.5 \mathrm{~W} / \mathrm{m} . \mathrm{K}$ for sintered clay brick, 1.8 $\mathrm{W} / \mathrm{m} . \mathrm{K}$ for glass and $0.4 \mathrm{~W} / \mathrm{m} . \mathrm{K}$ for wood. Wood and brick had significantly lower thermal conductivity than sandcrete.

Microstructure

The microstructure of sandcrete blocks with a sand to cement ratio of $6: 1$ and $50 \mathrm{wt} . \%$ replacement of sand by TODC is shown in Figure 10a. The angular dark regions are sand particles, with the cement and TODC forming the binding phase. This shows a dense microstructure containing low levels of porosity. Figure 10b shows the interface between the binder and sand particles at higher magnification. The cement and TODC cannot be distinguished and form a coherent interface with the sand particles.

\section{Discussion}

On the basis of the strength data, up to $70 \mathrm{wt} . \%$ sand could be replaced with TODC in sandcrete blocks when using a 6:1 ratio. This maintains the strength above the minimum of $3.45 \mathrm{MPa}$ specified for load bearing blocks [37]. In terms of water absorption and sorptivity, $50 \mathrm{wt} . \%$ TODC content gave the best results, and this can be considered the optimum addition for this w/s ratio. At TODC contents above 70 wt. $\%$ the packing between the sand and TODC was poor, the samples had low density and water absorption increased. There is a clear correlation between density, water absorption and sorptivity.

From the properties investigated it can be seen that there is an optimum level of sand replacement by TODC. On the basis of strength data up to $70 \mathrm{wt} . \%$ sand can be replaced with TODC as this produces 
sandcrete with strengths above the minimum 3.45 MPa specified for load bearing blocks [37]. In terms of the water absorption and sorptivity, $50 \mathrm{wt} \%$ TODC content yields the best result and therefore this level of TODC content is considered optimum.

From these results and the large quantities of TODC available in Nigeria could potentially be used in the production of sandcrete blocks. With typically 70 new wells drilled annually by each of the six major oil companies, industry statistics show that currently 873,600 tonnes of TODC are generated annually. There are issues with TODC disposal related to the available capacity of disposal sites and environmental concerns associated with leaching. As the volume of TODC generated continues to increase, more waste management contractors are treating ODC by LTTD, and this means that the volume of TODC will continue to increase.

At present most TODC are sent for disposal at landfill sites designated by the industry regulator the Department of Petroleum Resources. One such site is located within Onne Oil and Gas Free Zone (OOGFZ), an industrial area established to provide services to the industry. TODC are partly used as construction backfill material within OOGFZ and it is occasionally used for land reclamation purposes, although these are beneficial ruse applications they are not sufficient for the volume of TODC generated. In addition, construction backfill and reclamation applications within OOGFZ have limitations in terms of the quantities that can be used. This means that alternative demand-driven applications are needed and use of TODC in sandcrete blocks may provide an attractive opportunity. Other potential alternative applications for TODC that are also being investigated include use in geopolymers and as a raw material in sintered ceramic products.

\section{Conclusions}

This work has demonstrated that the sand in sandcrete can be replaced by oil drill cuttings treated by low temperature thermal desorption. For sandcrete with a 6:1 sand to cement ratio, replacing up to $50 \mathrm{wt} . \%$ of sand produces sandcrete with similar compressive strength to normal sandcrete but with increased density, reduced water adsorption and slightlty reduced thermal conductivity. Further work is required to assess the durability and leaching properties of sandcrete blocks containing treated oil drill cuttings. 


\section{Acknowledgements}

The authors are grateful to the Petroleum Technology Development Fund Nigeria for the overseas scholarship award to B. Mohammed and to the Worshipful Company of Paviors UK for the travel award to collect the initial oil drill cuttings samples.

\section{References}

1. Uzomaka OJ. An appraisal of methods of testing some physical properties of sandcrete blocks, Proc. of Instn. Civ. Engr, Part 2, 1978;8035(65):491-495.

2. Denis A, Attar A, Breysse D, Chauvin JJ. Effect of coarse aggregate on the workability of sandcrete, Cement and Concrete Research 2002;32(5):701-706.

3. Abdullahi, M., 2005, Compressive strength of sandcrete blocks in Bosso and Shiroro areas of Minna, Nigeria, AU J. T., 9(2), 126-131.

4. Omoregie, A. and Alutu, O. E., 2006, The influence of fine aggregate combinations on particle size distribution, grading parameters and compressive strength of sandcrete, Can. J. Civ. Eng, 33, 12711278.

5. Baiden, B. K. and Asante, C. K. O., 2004, Effects of orientation and compaction methods of manufacture on strength properties of sandcrete blocks, Construction and Building Materials, 18, 717-725.

6. Cisse, I. K. and Laquerbe, M., 2000, Mechanical characterisation of filler sandcretes with rice husk ash additions - Study applied to Senegal, Cement and Concrete Research, 30, 13-18.

7. Odigure, J. O., 2002, Deterioration of long-serving cement-based sandcrete structures in Nigeria, Cement and Concrete Research, 32, 1451-1455.

8. Gerrard, S, Grant, A., Marsh, R and London, C., 1999, Drill cuttings piles in the North Sea: management options during platform decommissioning, Centre for Environmental Risk, University of East Anglia, Research Report No 31. Norwich, United Kingdom.

9. Marsh, R., 2003, A database of archived drilling records of the drill cuttings piles at North west Hutton oil platform, Marine Pollution Bulletin, 46, 587-593.

10. Agha, G. U. and Irrechukwu, D. O., 2001, Experiences in the management of drill fluids and the regulatory control of associated cuttings in the Nigerian oil and gas industry, SPE International, SPE Paper 73932. 
11. Mohammed, B. and Cheeseman, C. R., 2006, Overview of the Management of Oil Drill Cuttings in Nigeria, In Proceedings of International Conference on Infrastructural Development and the Environment (ICIDEN), Abuja, Nigeria, September 10-15.

12. PPRC, 1993, Pollution prevention opportunities in oil and gas production, drilling, and exploration, The Pacific Northwest Pollution Prevention Research Center, Research report, Alaska, 4.

13. Louviere, R. J. and Reddoch, J. A., 1993, Onsite disposal of rig-generated waste via slurrification and annular injection, In Proceedings of SPE/IADC Drilling Conference, Amsterdam, 737-751.

14. Handique, G. K., Nayak, P. K., Bordoloi, S. and Dhal, S., 2002, Drill cuttings re-injection an ecofriendly offshore waste disposal technique, J. Indian Geophys. Union, 6(2), 87-91.

15. Sirevag, G. and Arthur, B., 1993, Improved method of grinding and reinjecting of drill cuttings, In Proceedings of SPE/IADC Drilling Conference, Amsterdam, 773-788.

16. Ji, G. D., Yang, Y. S., Zhou, Q., Sun, T. and Ni, J. R., 2004, Phytodegradation of extra heavy oilbased drill cuttings using mature reed wetland: an in situ pilot study, Environment International, 30, $509-517$.

17. Willis, J. M., Hester, M. W. and Shaffer, G. P., 2005, A mesocosm evaluation of processed drill cuttings for wetland restoration, Ecological Engineering, 25, 41-50.

18. Barker, G. W., Armstrong, K. W. and Adamson, T. J., 1992, Land treatment of petroleum hydrocarbon-based drill cuttings: pilot scale field study, In Proceedings of SPE Annual Technical Conference \& Exhibition, Washington, DC, 149-162.

19. Ladousse, A., Tallec, C., Chaineau, C. and Vidalie, J. F., 1996, Landfarming of drill cuttings, Society of Petroleum Engineers, SPE, 2, 31-34.

20. Zimmerman, P. K. and Robert, J. D., 1991, Oil-based drill cuttings treated by landfarming, Oil and Gas Journal, 89(32), 81-84.

21. Shang, H., Snape, C. E., Kingman, S. W. and Robinson, J. P., 2006, Microwave treatment of oilcontaminated North Sea drill cuttings in a high power multimode cavity, Separation and Purification Technology, 49, 84-90.

22. Al-Ansary, M. S. and Al-Tabbaa, A., 2006, Stabilisation/solidification of raw and synthetic North Sea petroleum drill cuttings for conversion into construction products, In M. Ilic, J.J. J.M. Goumans, S. Miletic, J.J.M. Heynen and G.J. Senden, Eds., Proceedings of Sixth International Conference on the Environmental and Technical Implications of Construction with Alternative Materials, Science and Engineering of Recycling for Environmental Protection, Belgrade, Servia and Montenegro, 551562. 
23. Eames, I., de Leeuw, B. and Conniff, P., 2002, Formation and remediation of drill-cutting piles in the North Sea, Environ. Geol., 41:5, 504-519.

24. Chaillan, F., Chaineau, C. H., Point, V., Saliot, A. and Oudot, J., 2006, Factors inhibiting bioremediation of soil contaminated with weathered oils and drill cuttings, Environmental Pollution, $144,255-265$.

25. Ellingsen, O., 1991, Oil contaminated drill cuttings. A new technology in cutting cleaning, In Proceedings of $1^{\text {st }}$ Int. Environment Northern Seas Conf. and Exhibition, Stavanger, Norway.

26. BS 410: 1986. Specification for test sieves.

27. BS EN 196-1:2005. Methods of testing cement. Part 1: Determination of strength.

28. BS EN 1015-3:1999. Methods of test for mortar for masonry. Part 3: Determination of consistence of fresh mortar (by flow table).

29. BS 1881-122: 1983. Testing concrete. Part 122: Method for determination of water absorption.

30. BS 12390-3:2002. Testing hardened concrete. Part 3: Compressive strength of test specimens.

31. BS EN 480-5:2005. Admixtures for concrete, mortar and grout - Test methods. Part 5: Determination of capillary absorption.

32. Alcantara E, O, Cheeseman, C. R., Knight, J. and Loizidou, M (2000). Properties of alkali-activated clinoptilolite. Cement and Concrete Research, 30, 1641-1646.

33. Sabir, B. B., Wild, S. and O'Farrell, M. (1998). A water sorptivity test for mortar and concrete. Materials and Structures, 31, 568-574.

34. Bai, J., Wild, S. and Sabir, B. B. (2002). Sorptivity and strength of air-cured and water-cured PCPFA-MK concrete and the influence of binder composition on carbonation depth. Cement and Concrete Research, 32, 1813-1821.

35. Lockington, D., Parlange, J.-Y. and Dux, P. (1998). Sorptivity and the estimation of water penetration into unsaturated concrete. Materials and Structures, 32, 342-347.

36. Neville, A. M. (1997). Properties of concrete. Addison Wesley Longman Limited, Essex, England, 489-490.

37. NIS 87:2004. Standard for sandcrete blocks. Nigerian Industrial Standard. 
Table 1 Composition of the sandcrete mixes prepared

\begin{tabular}{|c|c|c|c|}
\hline $\begin{array}{c}\left(\frac{\text { Sand }+ \text { TODC }}{\text { Cement }}\right) \\
\text { mix ratio }\end{array}$ & Sand $(\%)$ & TODC (\%) & $\begin{array}{c}\text { Water-to-Solids } \\
\text { Ratio }\end{array}$ \\
\hline \multirow{11}{*}{$6: 1$} & 100 & 0 & 0.125 \\
\hline & 90 & 10 & 0.125 \\
\hline & 80 & 20 & 0.125 \\
\hline & 70 & 30 & 0.125 \\
\hline & 60 & 40 & 0.125 \\
\hline & 50 & 50 & 0.125 \\
\hline & 40 & 60 & 0.125 \\
\hline & 30 & 70 & 0.125 \\
\hline & 20 & 80 & 0.125 \\
\hline & 10 & 90 & 0.125 \\
\hline & 0 & 100 & 0.125 \\
\hline
\end{tabular}


Click here to download line figure: TODC-Sandcrete paper Figures 0310810 for Waste and Biomass Valorization 100811.doc

Use of Oil Drill Cuttings as an Alternative Raw Material in Sandcrete Blocks, Waste and Biomass Valorization, Babagana Mohammed and

Christopher R. Cheeseman* Department of Civil and Environmental Engineering, Imperial College London, London SW7 2AZ, UK

(c.cheeseman@imperial.ac.uk)

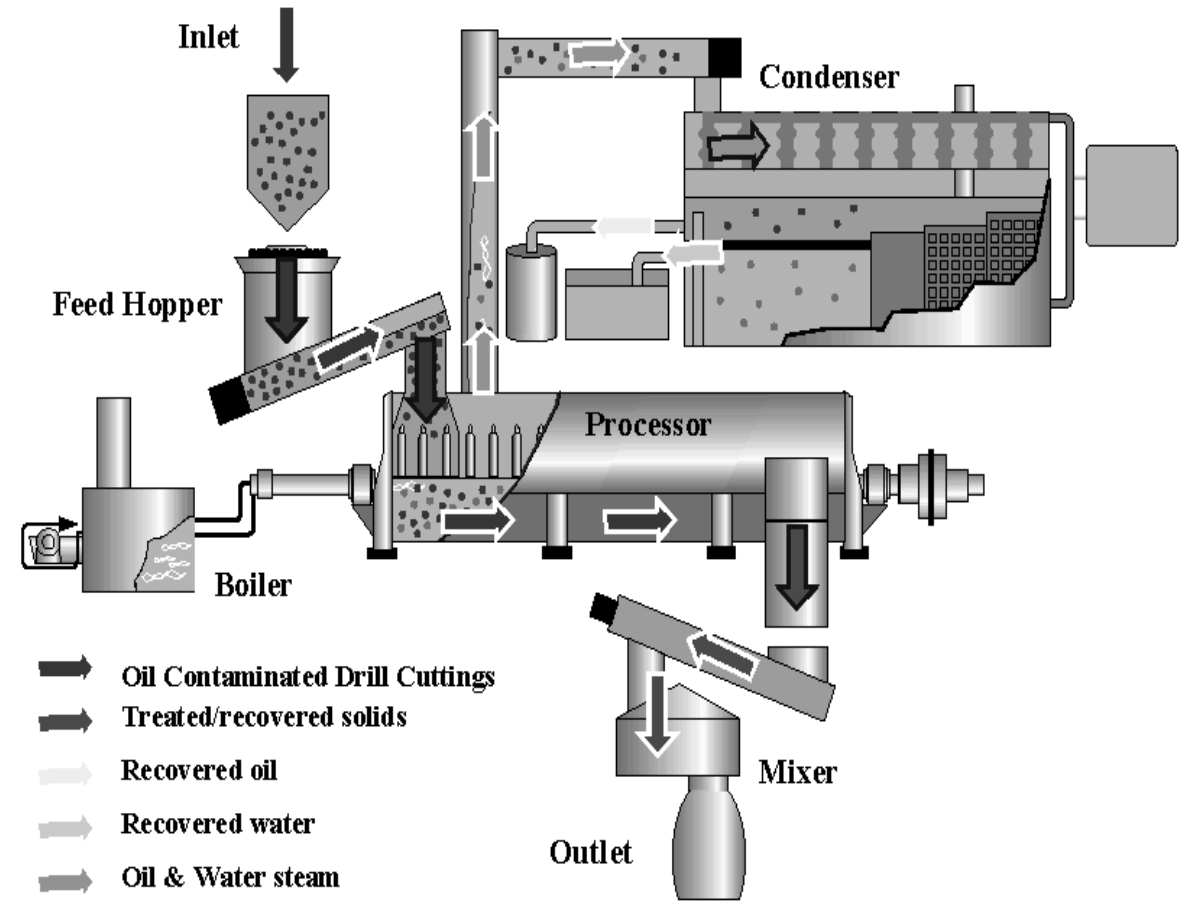

Fig. 1 Schematic diagram of a low temperature thermal desorption unit used to treat oil drill cuttings (DEL, 2006)

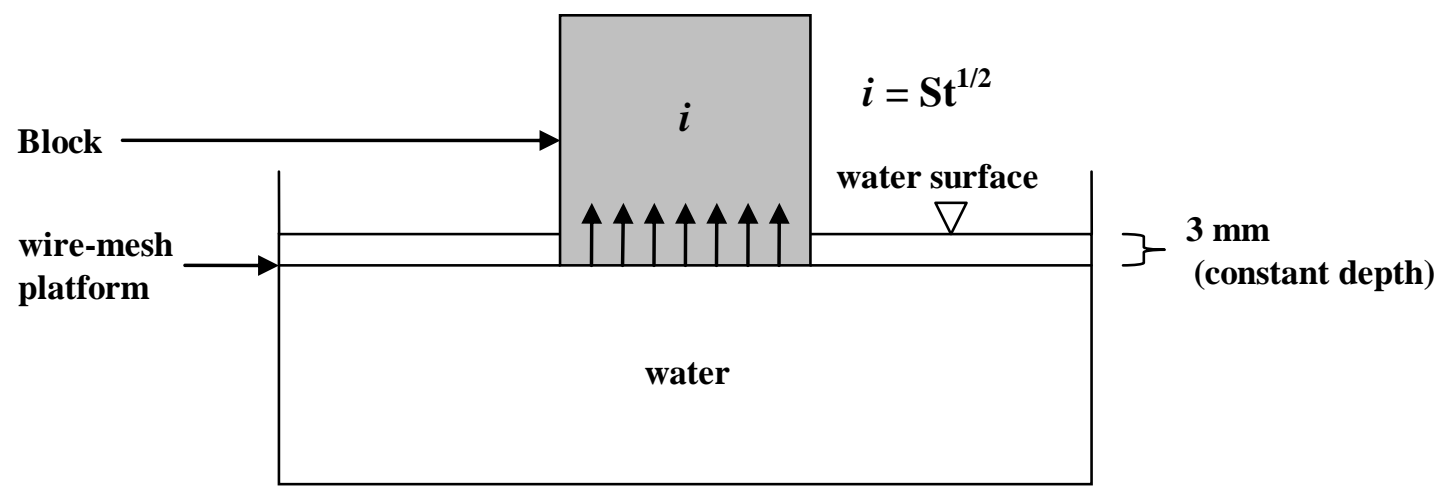

Fig. 2 Schematic diagram of the sorptivity test set-up and measurement process 
Use of Oil Drill Cuttings as an Alternative Raw Material in Sandcrete Blocks, Waste and Biomass Valorization, Babagana Mohammed and Christopher R. Cheeseman* Department of Civil and Environmental Engineering, Imperial College London, London SW7 2AZ, UK (c.cheeseman@imperial.ac.uk)

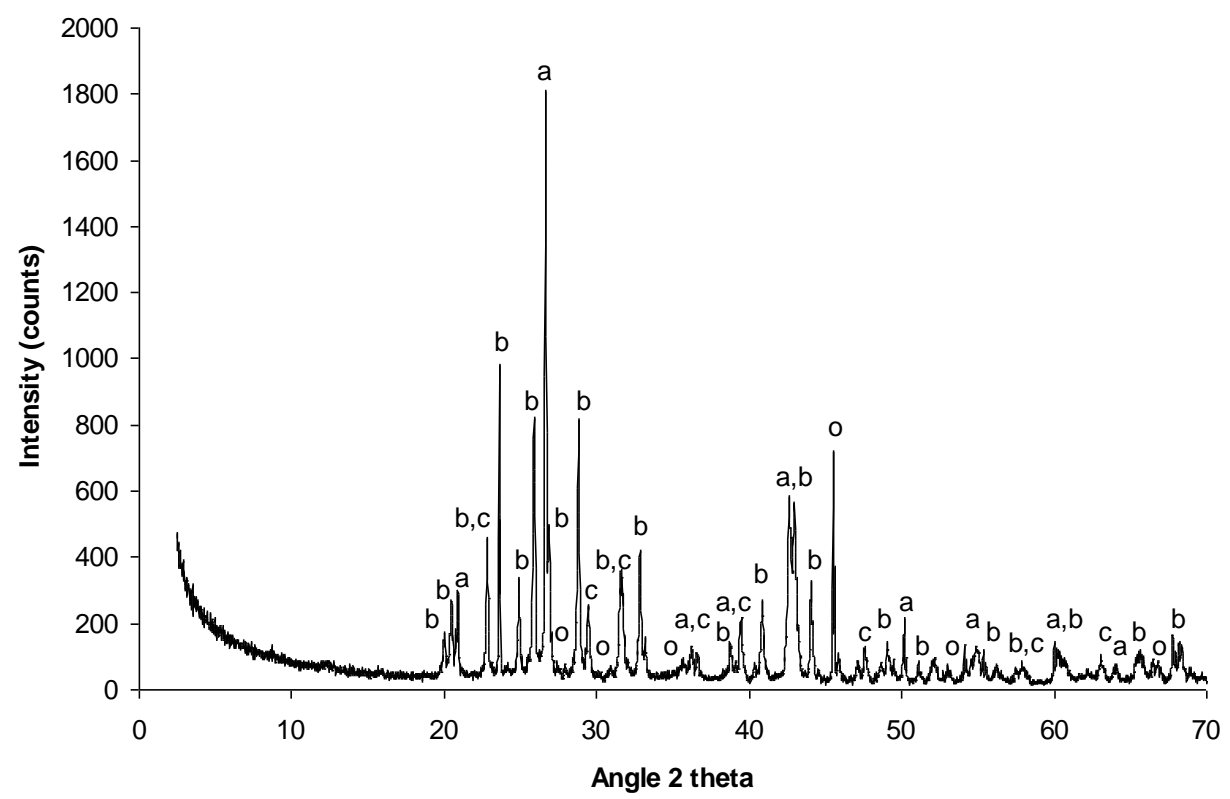

KEY: a - Quartz $\left(\mathrm{SiO}_{2}\right)$; b - Barite $\left(\mathrm{BaSO}_{4}\right)$; c - Calcite $\left(\mathrm{CaCO}_{3}\right)$; o - others $\left\{\right.$ Hematite $\left(\mathrm{Fe}_{2} \mathrm{O}_{3}\right)$; Ankerite $\left[\mathrm{Ca}(\mathrm{Fe}, \mathrm{Mg}, \mathrm{Mn})\left(\mathrm{CO}_{3}\right)_{2}\right]$; Kaolinite $\left(\mathrm{Al}_{2} \mathrm{Si}_{2} \mathrm{O}_{5}(\mathrm{OH})_{4}\right)$; Illite $\left.\left[\mathrm{Al}_{2}\left(\mathrm{Si}_{3.2} \mathrm{Al}_{0.8}\right) \mathrm{O}_{10}(\mathrm{OH})_{2} \mathrm{~K}_{0.8}\right]\right\}$

Fig. 3 XRD trace of the treated oil drill cuttings (as-received)

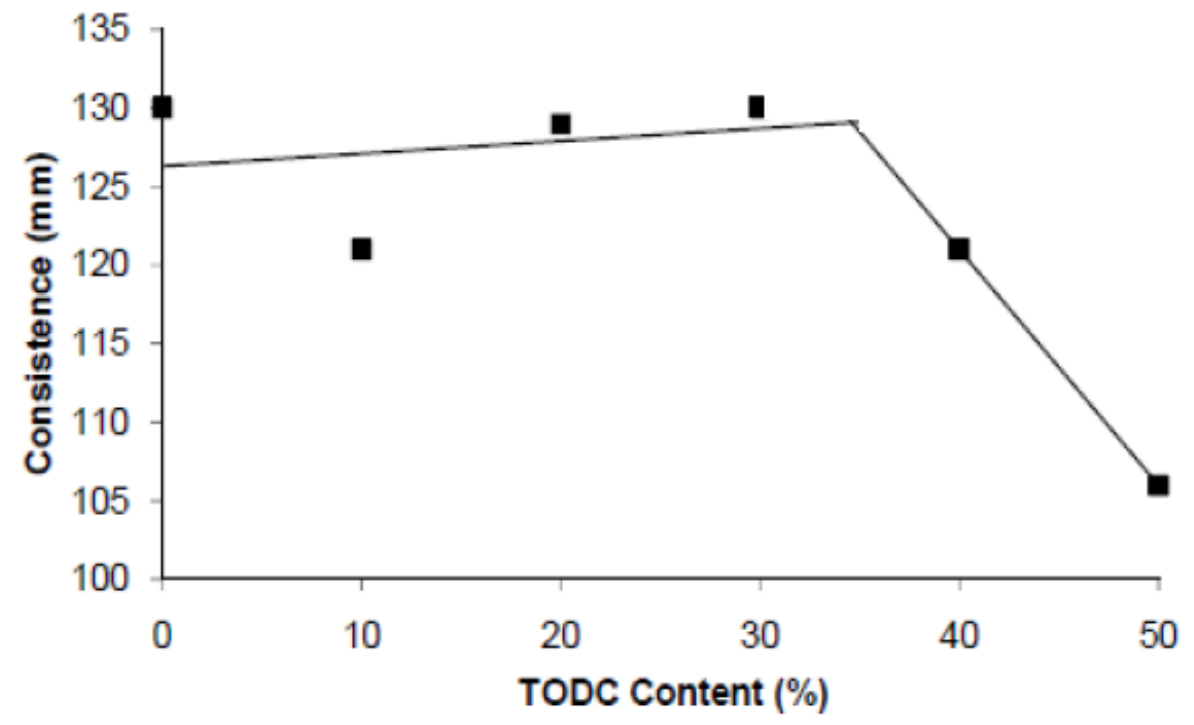

Fig. 4 Effect of TODC incorporation on consistence flows of the 6:1 mix at 0-50 wt $\%$ TODC contents 
Use of Oil Drill Cuttings as an Alternative Raw Material in Sandcrete Blocks, Waste and Biomass Valorization, Babagana Mohammed and Christopher R. Cheeseman* Department of Civil and Environmental Engineering, Imperial College London, London SW7 2AZ, UK (c.cheeseman@imperial.ac.uk)

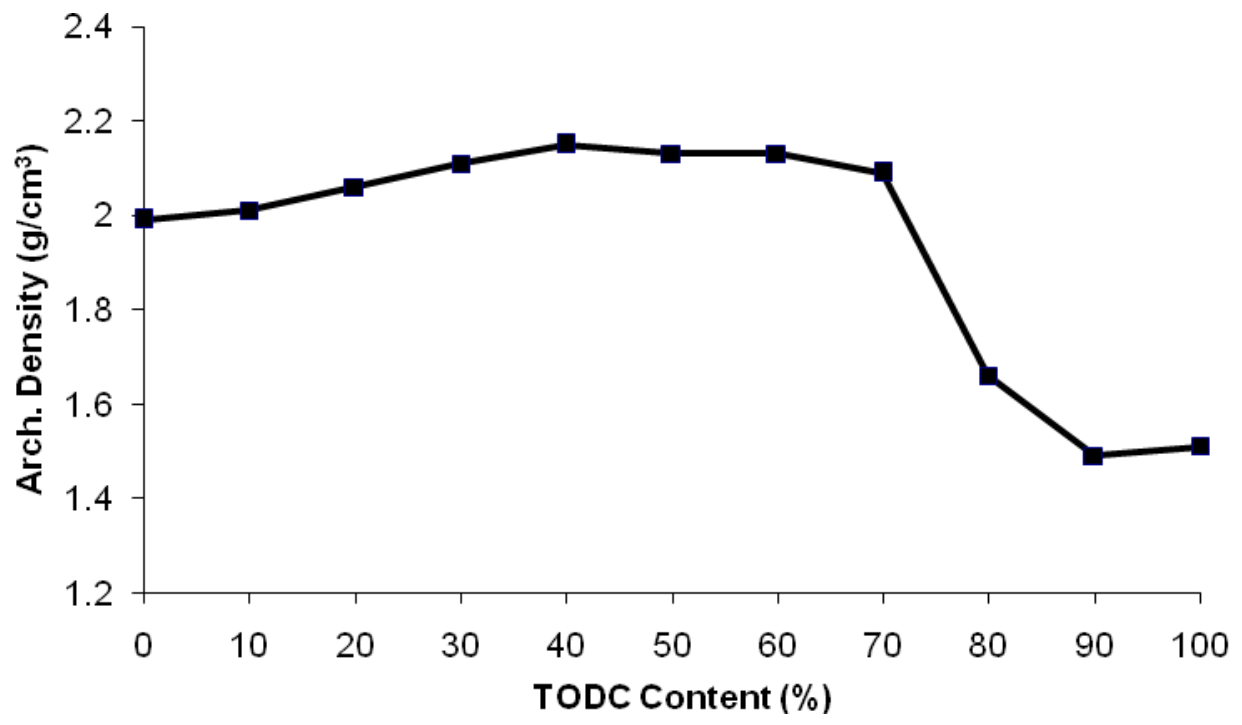

Fig. 5 Effect on density of sand replacement by TODC for the 6:1 mix

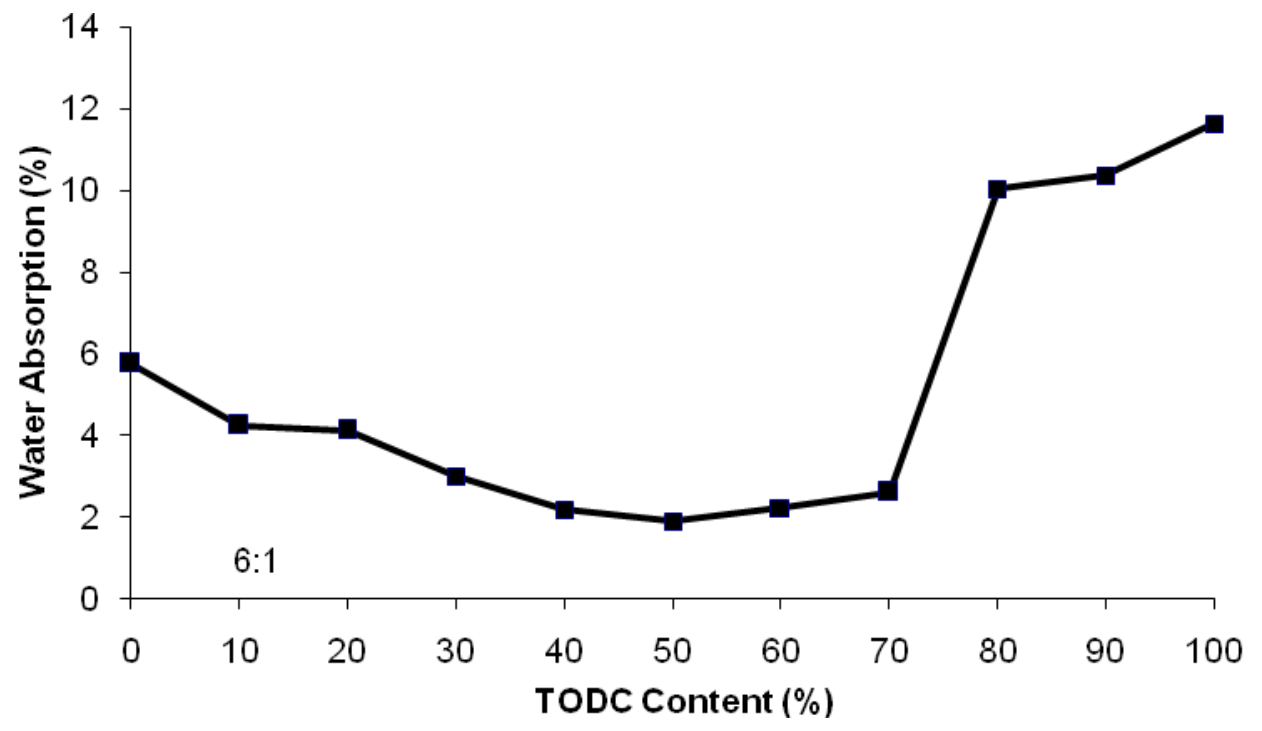

Fig. 6 Effect of TODC of sand replacement by TODC for 6:1 sand:cement mix 
Use of Oil Drill Cuttings as an Alternative Raw Material in Sandcrete Blocks, Waste and Biomass Valorization, Babagana Mohammed and Christopher R. Cheeseman* Department of Civil and Environmental Engineering, Imperial College London, London SW7 2AZ, UK (c.cheeseman@imperial.ac.uk)

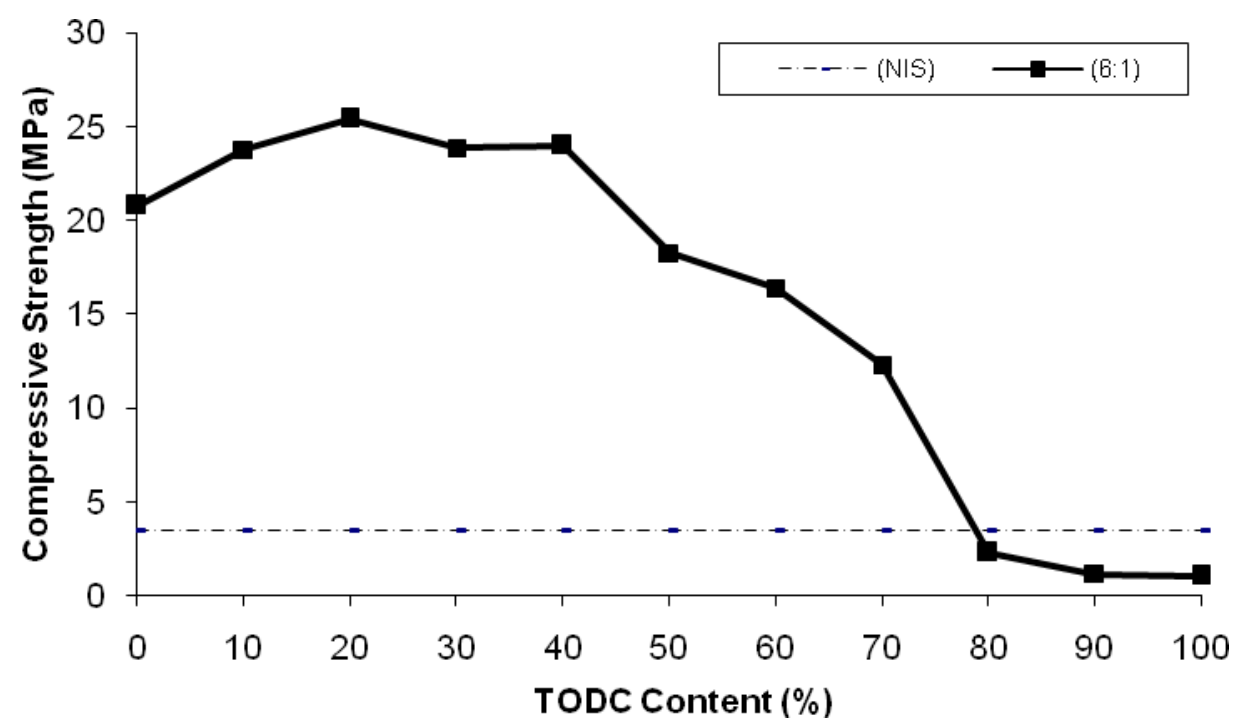

Fig. 7 Effect of TODC incorporation on unconfined compressive strength of the 6:1 mix at $0-100$ wt\% TODC contents as compared to the Nigeria Industrial Standard (NIS) value

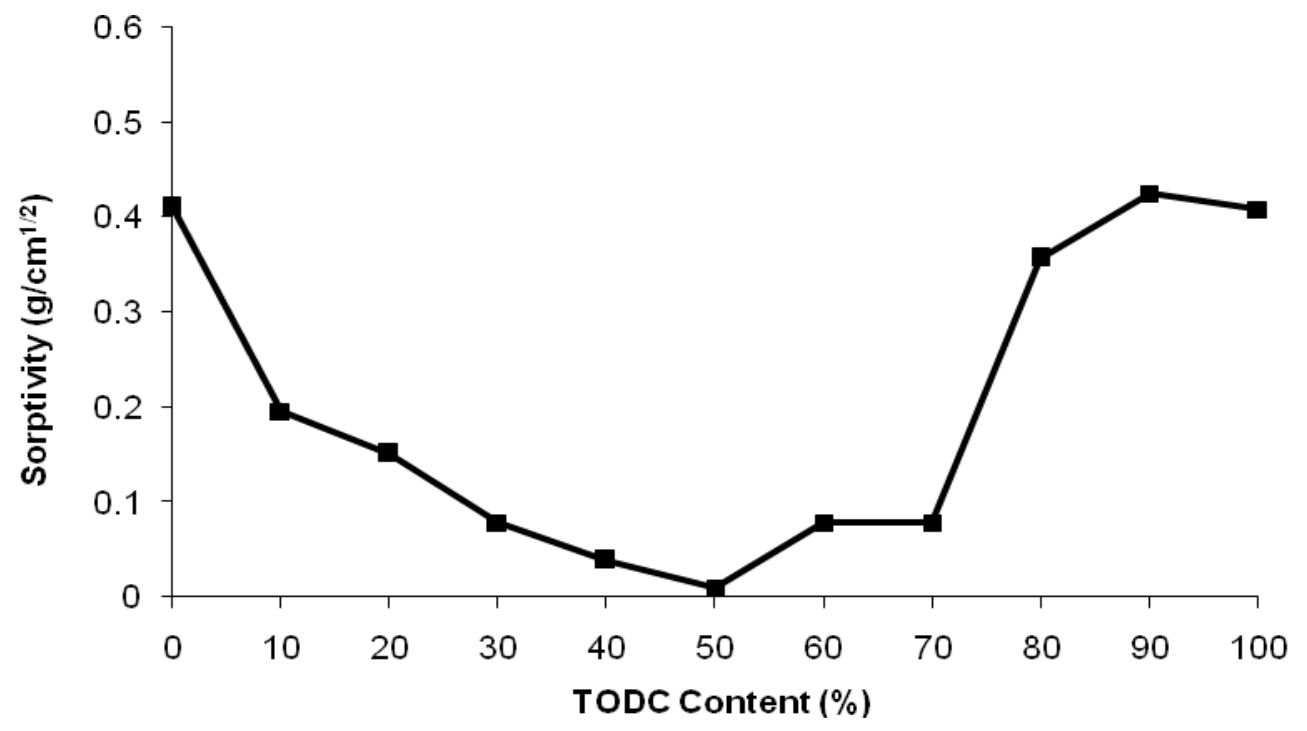

Fig. 8 Effect of TODC incorporation on sorptivity of the 6:1 mix at $0-100 \mathrm{wt} \%$ TODC contents 
Use of Oil Drill Cuttings as an Alternative Raw Material in Sandcrete Blocks, Waste and Biomass Valorization, Babagana Mohammed and Christopher R. Cheeseman* Department of Civil and Environmental Engineering, Imperial College London, London SW7 2AZ, UK (c.cheeseman@imperial.ac.uk)

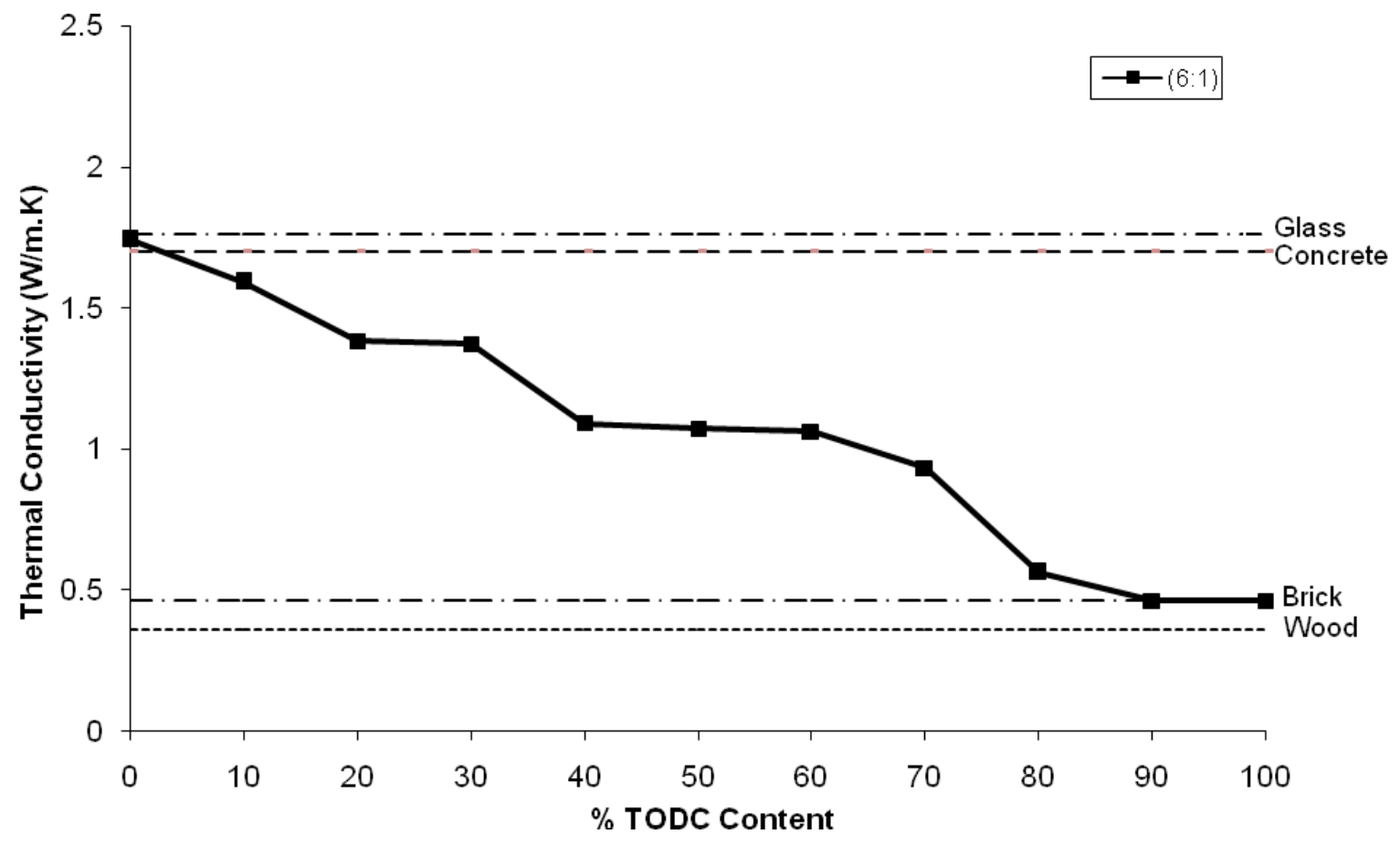

Fig. 9 Effect of TODC addition on the thermal conductivity of 6:1 sandcrete. 
(a)

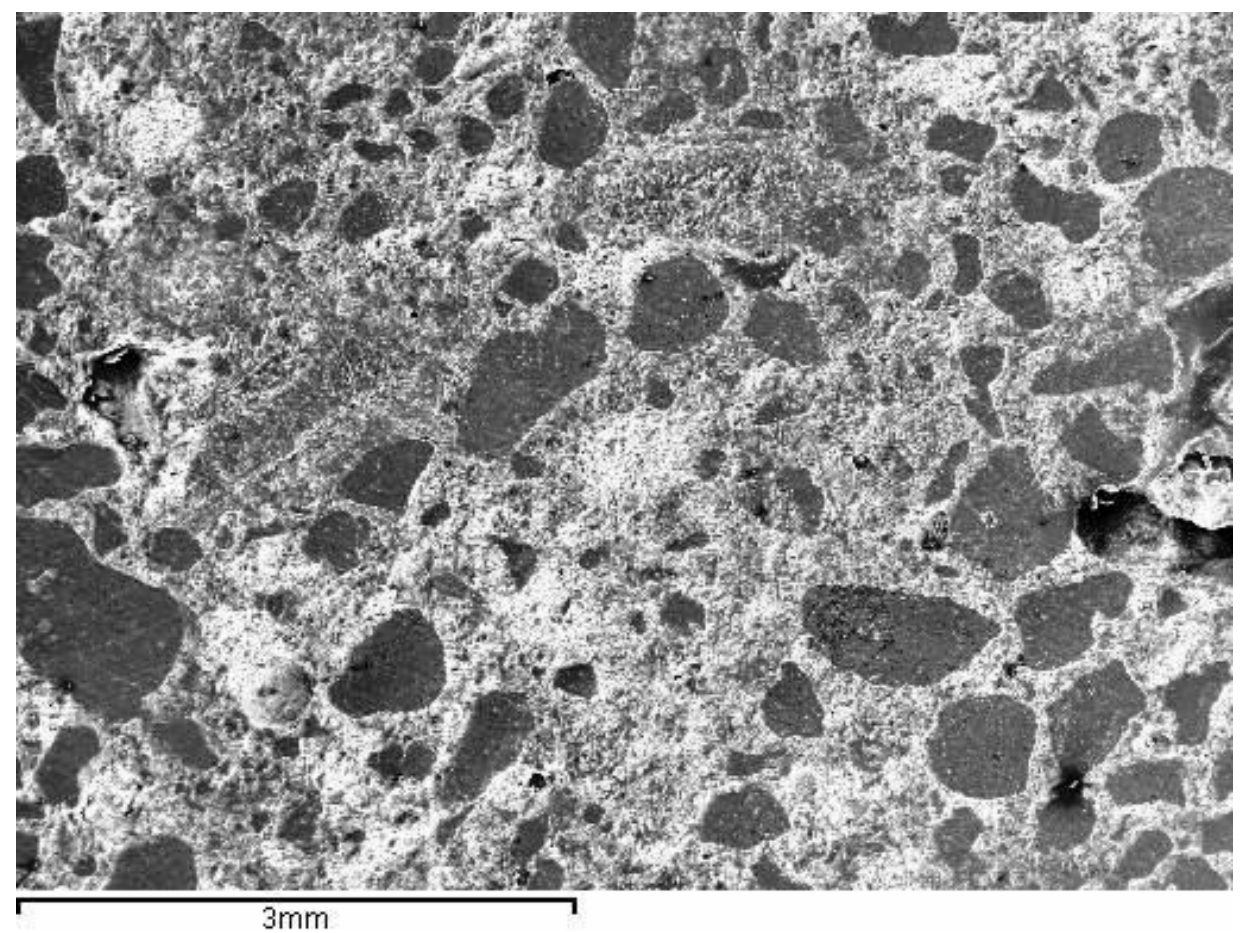

(b)

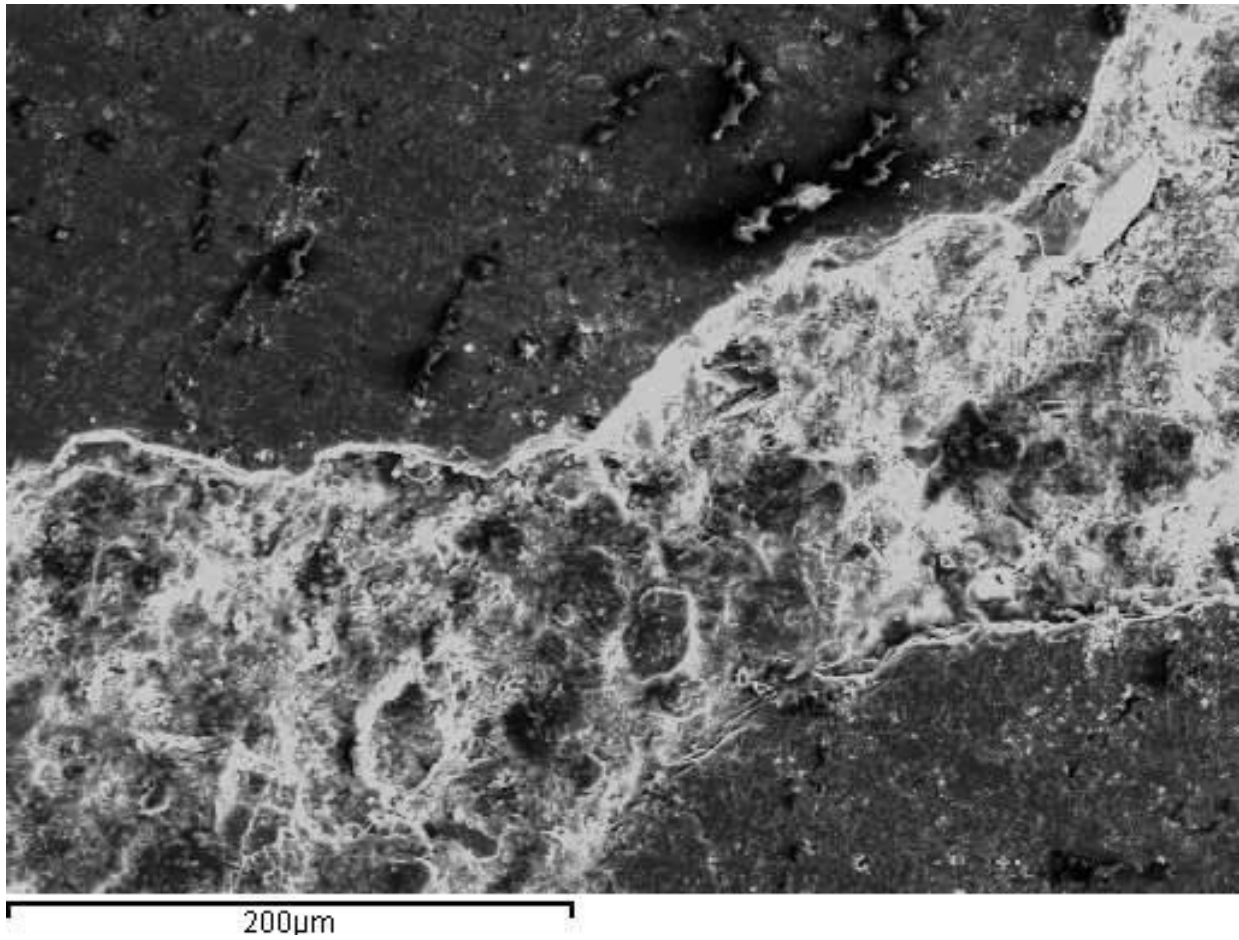

Fig. 10 Scanning electron microscope images of polished surfaces of 6:1 sandcrete blocks (a) 50:50 sand:TODC; and (b) binder/solids interface of 50:50sand:TODC block 